Meta

Journal des traducteurs

Translators' Journal

\title{
A Professional Approach to Translator Training (PATT)
}

\section{María Dolores Olvera Lobo, Bryan Robinson, Rosa María Castro Prieto, Enrique Quero Gervilla, Ricardo Muñoz Martín, Eva Muñoz Raya, Miguel Murillo Melero, José Antonio Senso Ruiz, Benjamín Vargas Quesada et José Luis Díez Lerma}

Volume 52, numéro 3, septembre 2007

URI : https://id.erudit.org/iderudit/016736ar

DOI : https://doi.org/10.7202/016736ar

Aller au sommaire du numéro

Éditeur(s)

Les Presses de l'Université de Montréal

ISSN

0026-0452 (imprimé)

1492-1421 (numérique)

Découvrir la revue

Citer cet article

Olvera Lobo, M., Robinson, B., Castro Prieto, R., Quero Gervilla, E., Muñoz Martín, R., Muñoz Raya, E., Murillo Melero, M., Senso Ruiz, J., Vargas Quesada, B. \& Díez Lerma, J. (2007). A Professional Approach to Translator Training (PATT). Meta, 52(3), 517-528. https://doi.org/10.7202/016736ar
Résumé de l'article

Les technologies de l'information sont un défi important pour les professionnels de l'enseignement de la traduction, métier étroitement lié au télétravail. Les auteurs présentent une nouvelle approche qui intègre les technologies à l'enseignement quotidien de matières liées à la traduction et des matières connexes, dans le cadre du DESS de traduction et d'interprétation, (d'une durée de quatre ans) offert à l'Université de Grenade (Espagne). Il s'agit d'une simulation en ligne des conditions de travail d'une agence de traduction. Les professeurs participants estiment que cette approche améliore la qualité de l'enseignement de la traduction à l'université. 


\title{
A Professional Approach \\ to Translator Training (PATT)
}

\author{
MARÍA DOLORES OLVERA LOBO \\ BRYAN ROBINSON \\ ROSA MARÍA CASTRO PRIETO \\ ENRIQUE QUERO GERVILLA \\ RICARDO MUÑOZ MARTÍN \\ EVA MUÑOZ RAYA \\ MIGUEL MURILLO MELERO \\ JOSÉ ANTONIO SENSO RUIZ \\ BENJAMÍN VARGAS QUESADA \\ JOSÉ LUIS DÍEZ LERMA \\ University of Granada, Granada, Spain \\ molvera@ugr.es
}

\begin{abstract}
RÉSUMÉ
Les technologies de l'information sont un défi important pour les professionnels de l'enseignement de la traduction, métier étroitement lié au télétravail. Les auteurs présentent une nouvelle approche qui intègre les technologies à l'enseignement quotidien de matières liées à la traduction et des matières connexes, dans le cadre du DESS de traduction et d'interprétation, (d'une durée de quatre ans) offert à l'Université de Grenade (Espagne). Il s'agit d'une simulation en ligne des conditions de travail d'une agence de traduction. Les professeurs participants estiment que cette approche améliore la qualité de l'enseignement de la traduction à l'université.
\end{abstract}

\section{ABSTRACT}

Information technology is a significant challenge for teachers involved in training translators, the prototype of teleworking professions. This article presents an approach that integrates technology into the day-to-day teaching of a range of disciplines. The University of Granada, Spain, offers a four-year first-degree program in Translation and Interpreting. The innovative, collaborative learning project we describe is an online simulation of work in a translation agency. We believe it enhances the quality of translator training within the university context.

\section{MOTS-CLÉS/KEYWORDS}

translation teaching, teaching model, virtual classroom, innovative learning project, collaborative work

\section{Introduction}

Information and communication technology (ICT) affects the working conditions of many professionals, translators above all, and presents new challenges and opportunities for teachers.

The gradual introduction of ICT into university teaching in general, and university classrooms in particular, is invaluable in degree programs aimed at preparing 
professional translators for their prototypical teleworking profession. Undergraduate translation students know they will be obliged to make use of ICT in their future working lives (Archer 2002; Askehave 2000; TTEL 2001). In particular, the use of computer tools involves the internalization of work routines that professional translators apply making it essential to familiarize trainee translators with the work systems and environment that are typical of the labor market.

While translators' clients and lay people generally focus on a command of languages as the cornerstone of quality for the professional translator, there are highly important tasks that can only be contemplated within the context of current ICT resources. These include documentation, terminology, desktop publishing and handling client and target reader relationships.

Today, the Internet is the greatest source of information in the world. It provides rapid access to information irrespective of geographical location. Consequently, gathering the information needed to understand a source text (ST), which might previously have taken up the major part of the time required to produce a translation, has been considerably reduced. However, today's translators must develop research strategies and evaluate the quality of information, tasks previously carried out with the help of other professionals such as librarians, information scientists, and subject matter specialists who are so vital to the success of their work.

Terminology has evolved in a similar way. Once, the fundamental issue was gaining access to obscure sources of specialized terminology. Online or CD-ROM digital resources now enable translators to access a wide range of lexicons that are quite regularly updated and expanded. This guarantees a greater degree of precision that is often greater than that expected by the specialists themselves. The fact that we can create digital text corpora has also changed the nature of the tasks terminologists need to undertake. Therefore, the nature of basic terminological problems has also changed: extracting terminology from specialized texts using computer tools, distinguishing between alternative denominations and storing the results for future translations are new skills they must acquire.

The issue of typesetting and layout, that is the graphic design of the text prior to delivery to the client whether for publication or immediate use, has been revolutionized and PCs now enable any user to construct a text of publication quality with no more sophisticated a tool than a word processor. Previously, translations were delivered in as simple a format as possible for professional typesetters to handle. The ICT revolution has placed responsibility for these tasks in the hands of the translator too, shortening the production line and broadening the professional requirements of translators. For example, translator trainees may well need to know how to insert an equation into a text, how to present the date in German, and the standard abbreviations for a telephone number in France. In short, translators are expected to be familiar with the requirements of format that specialized journals have accustomed us to. And they need to know how to produce these formats in a range of software applications that goes from the standard word processor to specialized software for the creation and management of web pages, as well as desktop publishing software such QuarkXpress ${ }^{\mathrm{TM}}$, PageMaker ${ }^{\mathrm{TM}}$ or FrameMaker ${ }^{\mathrm{TM}}$. Often, translators are also expected to handle operating systems such as Macintosh, which are particularly useful in the management of images and graphic aspects of texts. 
In addition, we have to consider the opportunities opened up by telecommunications. In barely ten years, translators have seen their local market become a worldwide market. It is nothing unusual for translators to work thousands of kilometers away from their clients and never actually meet them face to face. Translators can receive and deliver texts so rapidly that the timescale of their work has generally been cut by more than half. But this is just one aspect of the phenomenon. The change to an information society, in which millions of individuals can communicate with each other one-to-one (through web pages, by sending attachments) or in groups (via distribution lists, specialized forums, electronic publications) has meant that the need for translations has ballooned, converting many types of translation which were previously merely anecdotic and scarcely reached the public at large, into specializations (for example, the translation of recipes or non-specialized medical texts). All of this has led to a change in the format or presentation of many publications. For example, today it is almost unheard of for encyclopedias to be published without a corresponding CD-ROM or DVD. Often they are available only in electronic format because this much cheaper method of production enables publishers to update versions continuously. Similar changes and growing demand mean that, through the rigorous coordination of teams of translators, books can be published in a matter of months whereas previously almost two years might have been needed to place a text in the hands of the end user.

Thus, today's translators can define themselves as multilingual communicators and stress their command of this assortment of tools available since the beginning of the last decade. This does not mean that language competence has become less important but, on the contrary, it is only one facet of the competences they need to acquire.

Compartmentalizing learning into course modules with only minimal coordination of teaching does not allow for an overall view of the full task within a professional process. Neither does it facilitate learning about teleworking and teamworking, two of the keys to success for professional translators. Our pilot project introduces a sequence of tasks into the subject compartments. Students belong to teams of five, but not all team members follow the same course module. Individual students carry out tasks related to the specific module but which fulfill invaluable functions for the team as a whole. This project fulfils the Bologna Declaration in that it offers careercentered teaching with the focus on students and on the volume of work they undertake. Moreover, the project favors the understanding of learning objectives for all participants. It also brings productive work routines into the classroom and helps students to internalize these in a real context that should later give them a competitive edge when they join the labor market.

This article outlines the theoretical framework on which our approach to translator training is based and then describes the project. Aula.int, an online translation classroom developed in the Faculty of Translation and Interpreting of the University of Granada (Spain), is the practical application of our approach.

\section{Approaches to translator training: the state of the art}

For decades, translator training has followed the classical model of university teaching based on the lecture format. Teaching has been product-centered and students' products have been judged as "right" or "wrong." Today, this type of teacher-centered 
teaching is obsolete and has largely been replaced by a learner-centered alternative which favors student autonomy and eliminates the figure of the all-knowing teacher capable of resolving all problems (González Davies 2003).

Some consider translation and translator training to be an obstacle race (GerdingSalas 2000). Teaching is centered on each and every single one of the hurdles translators may encounter, from a first reading of the ST, to its reformulation, up to the final revision of the target text (TT). Teaching brings together a series of factors that enable trainee translators to fully develop translation competence (Nord 1991), constantly promoting a constructive, critical attitude and incorporating creativity in the classroom (Kussmaul 1995). The development of the concept of translation competence represents a turning point in the study and teaching of translation. Kiraly (2000) bases his classroom approach on the study and development of translation procedures. Translation competence, i.e. the construct of knowledge and skills needed to translate is made up of various sub-competences (PACTE 1998): communicative; extra-linguistic; instrumental-professional; psycho-physiological; transfer and strategic. These competences interact, and the student adds to them another, namely learning competence, which refers to the specific strategies a learner must develop.

These skills are acquired through practice as the task of translating has been described as procedural knowledge, i.e. knowing how, which is difficult to verbalize and is attained through practice and is essentially processed automatically (Hurtado Albir 1999). This is seen in opposition to declarative knowledge (Anderson 1983), i.e. knowing what, which is easy to verbalize, is acquiring by exposure, and its procedure is essentially controlled. Practice is complemented by the teaching of theoretical principles of the translation process in the belief that learners need to know the underlying mechanisms to improve their skills and management of a mental process.

It is widely accepted that the basic characteristics that specialized translators or interpreters require are (Gile 1995):

a) Good passive knowledge of their passive working languages.

b) Good proficiency in their active working languages.

c) Adequate knowledge of the contents of the texts they are to process.

d) Capacity to translate.

Given the technological revolution that has transformed both the teaching and practice of translation, we also have to take into account the application and knowledge of these new technologies and their application to translation. In the early nineties, some authors (Clark 1993; Wälterman 1993) began to consider the tools that could support translation and pointed to the great importance that computing would have in the short term. The Internet has been recognized as an instrument that enables us to improve the teaching and practice of translation (Askehave 2002) by making the application of new teaching methods possible and facilitating access to a vast range of permanently updated resources, such as bilingual corpora (Zanettin 1998).

Our professional approach to translator training (PATT) opens a new path using the simulation of team work as case studies form a part of training employees in many businesses. PATT moves us closer to the reality of professional translators in the 21st century. Translators are faced with linguistic difficulties and problems relating to typesetting and layout, work-induced stress and the ubiquitous inter-disciplinarity. 
Since that translation has evolved, our teaching methods should also adapt to the times and draw more closely on the realities of the market, casting aside the artificiality that sometimes characterizes translation activities in formal education (Gile 1995).

\section{A professional approach to translator training (PATT)}

On the whole, the process of translating implies a period of research for documentation and terminology which takes place in the pre-translations stage prior to the translation itself. During this stage, the learner acquires and processes both linguistic and specialized information related to the topic of the translation. This information is stored, in the translator's memory or in some form of support, and is later activated in the representation stage which corresponds to the process of linguistic conversion and communication in the form of the final product, the translated text.

In general terms, the translation process takes place as follows:

FIGURE 1

The translation process as information processing

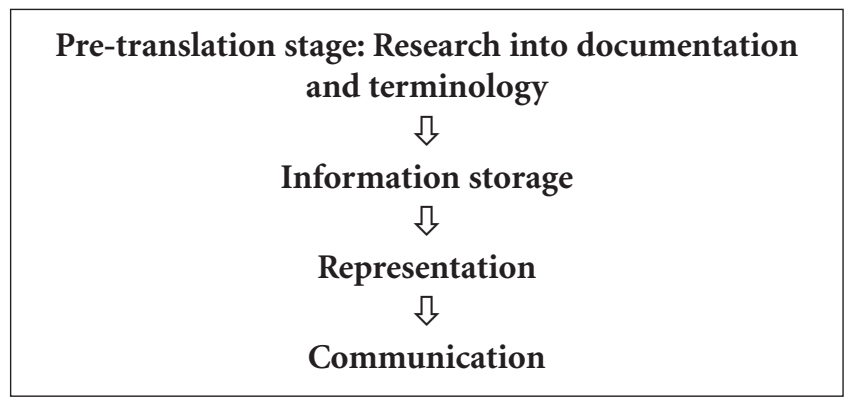

The objectives of our approach to translator training are:

1) To familiarize students with the methods of work typical of translation agencies by recreating the production line of the professional workplace. Students carry out the tasks of information scientists, terminologists, revisers, editors and typesetters. They even take on the responsibility of project supervisor, a role that is not normally included in teaching contexts but which is more and more important in the workplace.

2) To develop teleworking in teams, self-instruction and interdisciplinarity.

3) To provide a work setting with the tools needed by teachers and researchers to incorporate ICT in the classroom and reproduce the environment of the professional work context. Our approach allows us to obtain first hand information on the impact of ICT on university teaching.

4) To promote coordination between subject matter areas in the university teaching of translation.

One of the advantages of our approach is that the students incorporate skills and knowledge acquired in different, otherwise unconnected subjects of their curriculum. This provides them with an appropriate view of the range of productive tasks that they can relate to their University studies as a whole. The students themselves are responsible for the internal organization of the teams as each of them takes on one of the roles (information scientist, terminologist, and so on). Thus, self-learning is 
strengthened because, although students are assisted by their tutors, they are fully responsible for meeting the demands of the team member who is the next link in the chain. Professional relationships are established via electronic media between students who do not know each other. These strengthen the students' development of teleworking skills and test their communicative competence.

For each team, the order of tasks associated with each component is as follows:

1) Students responsible for documentation locate background texts based on the ST theme and parallel texts to fulfill the translation brief.

2) Students responsible for terminology systematically collate the terms relevant to the ST from the documentation received and record the relevant sources of terminology. Terminologists construct a conceptual framework to structure the content knowledge of the ST and facilitate learning.

3) Students responsible for translation render the text in the target language drawing on the resources provided by their colleagues.

4) Students responsible for revision and text formatting revise the TT and apply the required format.

5) Project managers assign tasks, coordinate work between members of the team and ensure work progresses adequately.

Two members of each team carry out work prior to the actual translation; one translates the text; another two work on the TT. The fourth stage in the production process - revision - is carried out by project managers who also take responsibility for setting objectives and deadlines and establish the frame within which the team will work by interpreting the brief. They also follow the progress of the project in order to ensure the team works efficiently.

Our translation project is part of translation course modules so that the work carried out by students within their teams forms a part of their coursework and is evaluated as an integral part of fulfilling the corresponding translation brief (Figure 2).

\section{Aula.int, online translation training: an innovative project in University teaching}

The University of Granada's first degree program in Translation and Interpreting includes course modules in documentation, terminology, desktop publishing, automatic and computer-aided translation, multimedia programming and professional management that co-exist alongside more traditional translation modules. This was the starting point of the innovative project we report on, which has been financed by the University of Granada Vicerrectorate for Planning, Evaluation and Quality in Teaching. This project has drawn together teachers from a correspondingly wide spectrum of research backgrounds.

\subsection{Description of the project}

The Aula.int project follows the basic structure of any training simulation aimed at bridging the gap between the academic and professional worlds. The course modules currently involved in the project are: 


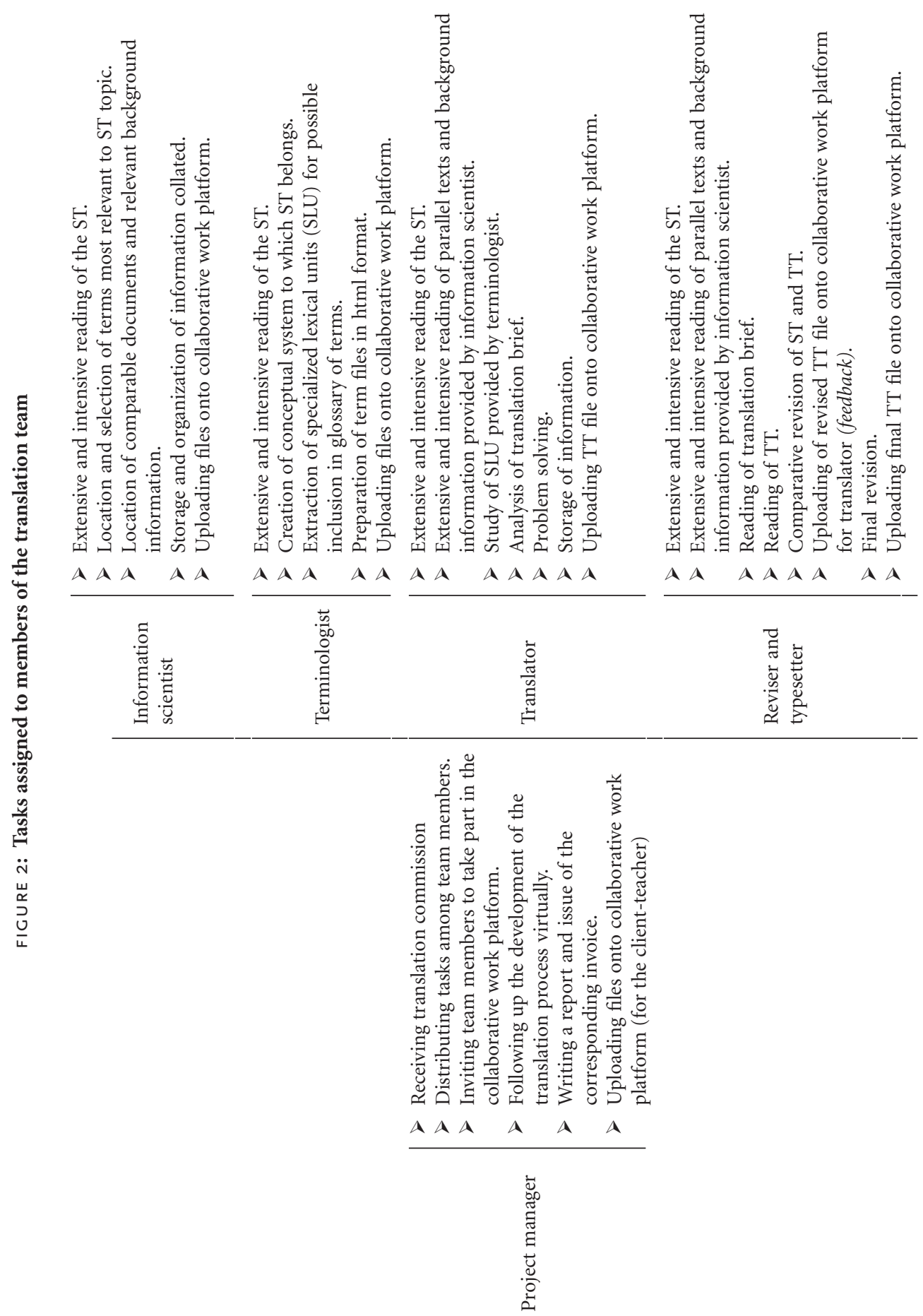


- Applied documentation for translation; Scientific and technical documentation; Legal, economic and commercial documentation.

- Terminology I and II. Scientific and technical translation

- Spanish into English

- English into Spanish

- French into Spanish

- Italian into Spanish

- Russian into Spanish

- Portuguese language

- Revision, editing and desktop publishing

Given that Aula.int is an open, ongoing project, teachers and students of other specializations and language combinations are expected to become involved in the future.

The Aula.int web site (http://aulaint.ugr.es) is a meeting point for participating students and tutors. It has two distinct areas, one public and one with access restricted to participants. The open area provides information about the project, teachers, and course modules involved. One of the major components is a work guide set out as a tutorial and designed to help students with the tasks and roles they undertake in the project. Moreover, the website provides links to information related to the translation briefs and the teams, online resources and a reference corpus in the languages of the course modules involved.

The restricted area gives access to the online collaborative work platform BSCW (Basic Support for Cooperative Work, http://bscw.gmd.de). This is an asynchronous, shared work space that facilitates online collaboration between team members. The use of BSCW clearly benefits the project. For instance, BSCW enables students:

- To create a specific work space for each translation team that they can access via an Internet navigator.

- To upload and download documents and files to their work space enabling them to include additional information by creating notes.

- To store documents for their own use, to share and organize documents in folders, and view or modify documents with other team members.

- To plan and organize meetings.

- To exchange ideas with team members and tutors.

- To receive and deliver the documents produced in each stage of the process.

The software platform enables tutors to monitor learning activities as they take place.

\subsection{Organigram of Aula.int}

In order to fulfill the objective of integrating the different course modules involved in the project, Aula.int has one Coordinator and a number of tutors take responsibility for different aspects of the project. The functions assigned to each are:

- Coordinator: responsible for overall organization, the coherent and efficient functioning of the project.

- Technical supervisor: coordinates the creation maintenance and updating of the website and the BSCW platform.

- Content supervisor: oversees the adequacy of choice of texts for translation briefs and sources of online reference material. 
- Translation brief supervisor: advises and acts as a link between the project managers of the different teams.

- Teachers: tutor the students who are following their course modules during the simulation period. Ultimately, they are responsible for the translation briefs.

- Students: form translation teams in which each member takes on a role and fulfills specific tasks in the translation process.

For many students, participation in this project is their first contact with ICT, teleworking and collaborative learning. In itself, this new approach helps overcome potential demotivation and guarantees that students achieve their learning objectives on schedule.

\section{Application of PATT to teaching}

This model has been applied in two stages. First, the basic model was validated in a pilot version with selected students, then it was extended to all students following the course modules involved.

\subsection{Validation: the pilot project}

During the pilot phase three translation briefs were set for each language combination (French into Spanish, English into Spanish, and Spanish into English). Each brief was designed to take two weeks.

Teachers informed students of the innovative nature of the Aula.int project. From some 40 volunteers teams were selected according to the following criteria: all students should have completed or currently be studying all or most of the course modules involved (the majority were fourth year undergraduates); they should have attained or be expected to attain above average grades in these course modules; they should have a lighter learning load in the semester in which the project was to take place to ensure participation did not have negative consequences on their studies.

Fifteen students were selected and each was assigned a role within a specific team of five on the basis of their academic record. Each team member could take a different role in each translation brief so as to experience roles other than that of translator.

A general meeting was held to brief participants prior to beginning the pilot project. Procedural norms were established for students and teachers: students were required to fulfill the translation tasks and teachers had to follow the development of the project as a whole for each of the briefs, paying special attention to aspects concerning their own course modules.

The process of validation served as an interesting useful trial, permitting us to detect a series of difficulties that the students had to face in fulfilling the briefs. This made it possible to resolve or mitigate these as far as possible with a view to the later open application of Aula.int which would involve a far larger number of students.

In addition to the predictable difficulties inherent in the translation itself, students reported that the problems they most frequently had to deal with were related to technical aspects of the project, a lack of communication with some team members, or the inability of some individuals to cope with the workload assigned. Occasionally, these problems delayed the work schedule and resulted in work being duplicated. Knowledge of these deficiencies led us to introduce the BSCW platform instead of 
using e-mail for teachers and students to communicate. Our initial ad-hoc restricted mailing list proved inefficient and was replaced by the wider range of communication opportunities offered by BSCW.

\subsection{PATT: second phase application}

The second phase of development saw our project extended to a greater number of students and language combinations. The approach was based on translation course modules, and students carried out translation briefs in teams, adopting the set roles. In order to carry out the briefs they needed to draw on knowledge and skills acquired in course modules on documentation, terminology and translation courses. Table 1 summarizes data on participation.

TABLE 1

Aula.int in figures

\begin{tabular}{|c|c|c|c|c|c|c|}
\hline $\begin{array}{l}\text { Language } \\
\text { combination }\end{array}$ & $\begin{array}{l}\text { Spanish } \\
\text { into } \\
\text { English }\end{array}$ & $\begin{array}{l}\text { English } \\
\text { into } \\
\text { Spanish }\end{array}$ & $\begin{array}{c}\text { Italian } \\
\text { into } \\
\text { Spanish } \\
\end{array}$ & $\begin{array}{c}\text { Portuguese } \\
\text { into } \\
\text { Spanish } \\
\end{array}$ & $\begin{array}{l}\text { Russian } \\
\text { into } \\
\text { Spanish }\end{array}$ & Totals \\
\hline Activity & Obligatory & Optional & Obligatory & Elective & Obligatory & \\
\hline Follow-up & $\begin{array}{l}\text { Online and } \\
\text { in class }\end{array}$ & $\begin{array}{l}\text { Online and } \\
\text { in class }\end{array}$ & $\begin{array}{c}\text { Online and } \\
\text { in class }\end{array}$ & Online & $\begin{array}{c}\text { Online and } \\
\text { in class }\end{array}$ & \\
\hline $\begin{array}{l}\text { Students } \\
\text { registered }\end{array}$ & $\begin{array}{c}81 \\
40.50 \%\end{array}$ & $\begin{array}{c}50 \\
25 \%\end{array}$ & $\begin{array}{c}21 \\
10.50 \%\end{array}$ & $\begin{array}{c}30 \\
15 \%\end{array}$ & $\begin{array}{c}18 \\
9 \%\end{array}$ & 200 \\
\hline $\begin{array}{l}\text { Students } \\
\text { participating }\end{array}$ & $\begin{array}{c}81 \\
60 \%\end{array}$ & $\begin{array}{c}15 \\
11.11 \%\end{array}$ & $\begin{array}{c}15 \\
11.11 \%\end{array}$ & $\begin{array}{c}8 \\
5.93\end{array}$ & $\begin{array}{c}16 \\
11.85 \%\end{array}$ & 135 \\
\hline $\begin{array}{l}\text { Total number } \\
\text { of different } \\
\text { briefs }\end{array}$ & 16 & 3 & 1 & 2 & 1 & 23 \\
\hline $\begin{array}{l}\text { Total number } \\
\text { of teams }\end{array}$ & 16 & 3 & 3 & 2 & 5 & 29 \\
\hline
\end{tabular}

\subsubsection{Difficulties encountered}

Although the majority of students participated in obligatory tasks, for some Aula.int was optional. This is one of the reasons not all of the students registered in each course module took part in one or other of the PATT translation briefs. In addition, some students found it difficult to attend classes regularly for professional or academic reasons and consequently did not participate in the continuous evaluation. However, even though it is not reflected in Table 1 , several students participated in the project in different language combinations simultaneously and these are the students who show the greatest levels of enthusiasm for this kind of course work.

While the majority of the translation teams carried out the roles and distributed the tasks as suggested in PATT, in some cases special circumstances made variations necessary. The language combination Portuguese-Spanish is taught during Year 2 of the degree program which means that these students participated prior to their introduction to Terminology. Consequently the role of terminologist was difficult for them to undertake with any degree of autonomy and they were aided by the course module tutor. 
Almost all the students of Russian-Spanish translation were exchange students and their mother tongue was not Spanish. In addition, they lacked preparation in subjects such as Documentation and Terminology which made it difficult for them to operate autonomously in the corresponding roles. This led to the teacher taking on the project leader role and directing their work. In this case also, only one student was involved in pre-translation tasks.

Teacher follow-up was via the online resource (BSCW), in class, and through direct contact with individual students.

\section{Conclusions}

We believe that the PATT approach in this innovative teaching project Aula.int has matured enough to cope with the large number of students and teachers involved. In the short-term, we intend to maintain and update the website in order to introduce further language combinations and translation specialties and develop instruments to measure and evaluate PATT via questionnaires and pre- and post-project students interviews in order to establish their views on participating in Aula.int. These tools are intended to assess the impact of this innovation on students and determine their levels of knowledge and expectations, their capabilities as ICT users and their familiarity with the range of computer applications involved, their opinions on teamwork and the specific knowledge of the course modules involved.

\section{REFERENCES}

Anderson, J. R. (1983): The Architecture of Cognition, Cambridge, Harvard University Press.

Archer, J. (2002): "Internationalisation, technology and translation," Perspectives-Studies in Translatology 10-2, p. 87-117.

Askenave, I. (2000): “The internet for teaching translation,” Perspectives: Studies in Translatology 8-2, p. 135-143.

Clark, R. (1993): "Computer-assisted translation: the state of the art," in C. Dollerup, A. Lindegaard (eds), Teaching translation and interpreting 2, Denmark, Elsinore, p. 301-308.

Gerding Salas, C. (2000): “Teaching translation. Problems and solutions," Translation Journal 4-3, <http://accurapid.com/journal/13educ.htm> [Consultation date: December 2003].

Gile, D. (1995): Basic Concepts and Models for Interpreter and Translator Training, Amsterdam/ Philadelphia, John Benjamins Publishing Co.

GonzÁlez Davies, M. (coord.) (2003): Secuencias. Tareas para el aprendizaje interactivo de la translation especializada, Barcelona, Octaedro EUB.

Hurtado Albir, A. (1999): Enseñar a traducir. Metodología en la formación de translators e intérpretes. Teoría y fichas prácticas, Madrid, Edelsa.

Kiraly, D. C. (2000): A Social Constructivist Approach to Translator Education: Empowerment from Theory to Practice, Manchester, St. Jerome.

Kussmaul, P. (1995): Training the Translator, Amsterdam/Philadelphia, John Benjamins Publishing Co.

PACTE. (2000): "Acquiring translation competence. Hypotheses and methodological problems of a research project," in Beeby Lonsdale, A., Ensinger, D. and M. Presas Investigating Translation, Amsterdam, John Benjamins Publishing.

Nord, C. (1991): Text Analysis in Translation: Theory, Methodology, and Didactic Application of a Model for Translation-oriented text-analysis, Amsterdam, Rodopi.

SAINZ, M. J. (1993): "Student-centred corrections of translations," in Dollerup, C. and A. LinDEGAARD (eds), Teaching Translation and Interpreting 2, Denmark, Elsinore, p. 133-143. 
528 MetA, LII, 3, 2007

TTEL (2001): Translator Training and e-learning: An on-line symposium, Intercultural Studies Group, Tarragona, pp. 17-25 November 2001, <http://www.ice.urv.es/trans/sociolinguistics/ elearning/elearning.html> [Consultation date: September 2002].

WÄltermann, D. (1993): “Machine translation systems in a translation curriculum," in Dollerup, C. and A. LindegaArd (eds), Teaching translation and interpreting 2, Denmark, Elsinore, p. 309-317.

Zanettin, F. (1998): "Bilingual comparable corpora and the training of translators," Meta 43-4, p. 616-630. 